\title{
THE THIRD WAY OF GOVERNING THE COMMON POOL RESOURCES EXCEPT PRIVITIZATION AND EXPROPRIATION: ALANYA FISHERS THAT INSPIRED THE NOBEL PRIZE
}

\author{
Sedef OLUKLULU ${ }^{1}$
}

\begin{abstract}
Common pool resources have two features according to economic classification of goods: it is difficult to exclude the individual from benefiting the good and additional individual reduce the benefit of the other individuals. Individuals that are using the same scarce reasource can realize maximization of their own benefit by maximazing their interest in the present time. The motivation to maximaze the individual interest and difficulty of excluding the individuals from using the good, named tragedy of commons, cause detoriation and not able to transfer to the next genaration. In the assumption of full information, prisoner's dilemma means rational strategies can lead to irrational consequences if there are common pool resources. Thus, the fundemantals of social scineces, political philosophy and ethics are also related to this. One of the policy advice is to exproprate the natural resources like grazing lands, forests and fisheries so that central goverment can control and regulate. An other policy advice, to avoid the tragedy of commons, is to privatizate the common pool resource and establish the individual property rights. "Public-like" and "private-like" institutions can also be succesful of governing the common pool resources. Local Alanya inshore fishing cooperation is a good example of establishing the efficent rules by the participants as an self governed common pool resource.
\end{abstract}

Keywords: Common Pool Resources, Tragedy of Commons, Prisoner's Dilemma, New Institutional Economics

JEL Code: Q22, H41

\section{Introduction}

New Institutional Economics (NIE), refuse the unrealistic assumptions of the neoclassical economy such as full information of the individuals and organizations and NIE accept the assumptions of scarce of the resources and the competition (Stilwell, 2019: 37). The individuals in the community want to maximize their interest by forming organizations. The individuals change the rule of the organizations to realize their requests. Institutional arrangement that determine the rules of the game is about whether they compete against each other or they cooperate (Çetin, 2012: 46).

Common poll resources are systems that the usage of the resource of a person decrease the amount of quantity of others. Although the additional individual that benefiting the common good diminish the benefit of the others, it is impossible or overcosting to restrain the individuals from benefiting the goods. The rational individual who knows that it is impossible to exclude from benefiting the common goods prefer free riding or overuse rather than to contribute. If everybody in rational behavior prefer to free riding or overuse, the common benefit or common good can not sustain its existence (Ostrom, 2015: 6).

\footnotetext{
1 Res. Asst. Dr., Anadolu University Faculty of Economics and Administrative Sciences, sedefcelik@anadolu.edu.tr
} 
If we approach with the fundamental assumptions of the neoclassical economy, the tragedy of commons is the inevitable consequence of the common goods. However in the real world the individuals have experienced the rational behaviors can cause to waste the common good or not to generate the common benefits. The importance of this presentation is the assumption of the rational individual has neither helped to explain the real world matters nor solve them. The purpose of the presentation is introducing some other consequences that are not the tragedy of commons if the individuals using the common pool resources could communicate and cooperate with each other. The fishers of Alanya had experience many unfavorable practices while catching the ownerless fishes in the sea. The method and the extent of this presentation is studying the solution of they found by means of communication and trust each other.

\section{The Theoretical Fundamentals of The Tragedy of Commons}

The Code of Justinian had stated water and the other natural resources as common goods : "the following things are by natural law common to all - the air, running water, the sea and consequently the seashore." (Institutes of Justinian). Aristotle had stated in his book named Politics (B.C. 350) as "what is common to the greatest number has the least care bestowed upon it. Everyone thinks chiefly of his own, hardly at all of the common interest" (Politics, Book II, ch. 3). In Islam the prophet Muhammad's sayings is: "Mankind are common in water, grass and fire." The goods like this had state-owned and right to benefit belonged to the public. In mecelle (Ottomon code of civil law): "Everyone can use the permissible grass, trees and water, nobody can prohibit." Common goods like air, water are also out of the subject of private propriety in India. Tragedy of commons had described by Hardin as deterioration of overused assets because the assets presents common benefit and use cannot be limited and also no responsibility can be given to the users (Hardin, 1968,1244).

\subsection{Prisoner's Dilemma}

Prisoner's dilemma is a non-cooperative game that every player have full information. (Dawes, 1975). In the non-cooperative games player to player communication is not possibile. The assumption of full information means players know the structure and the consequences of the play. The dominant strategy of prisoner's dilemma is the strategy of self improvement whatever the other player chooses (Ostrom, 2015:4). In this case prisoners would equilibrate in the third best result. The best result for themselves would not Pareto-optimal. The impossibility of the cooperation of rational individual effects the fundamentals of social science (Campbell, 1985: 3).

\subsection{The Logic of Collective Action}

The rational individual would fail to behave for common or group interest if there is no special device providing them to act for common interest or the number of individuals in the group is very few (Olson, 1965: 2).

\section{Common Features of Theoretical Foundations}

There is a free-riding problem in the tragedy of commons, prisoner's dilemma and the logic of collective action. If one person cannot be excluded from the benefit of the other, the others are motivated not to contribute to the collective effort, but to benefit from the contribution of others. The assumption of rational preferences in all the three situations hinders collective 
action, causing commoners to fail (Wall, 2014: 82). Common goods are deteriorated or depleted due to leaving the common good for the sake of maximizing individual benefit or the overuse of common goods with the outgrowth of the population (Ergüder \& Uymaz, 2014: 134).

\section{Fisherman in Alanya}

Institutional durability rules should be amended when necessary, and this is expressed as a feature of permanent institutions (Kenneth, 1989: 132). Ostrom has identified eight common characteristics in the design of durable institutions that include common resources:

Table 1. Characteristics of Durable Institutions in the Use of Common Goods

\begin{tabular}{|l|l|}
\hline Feature & Clearly determined boundaries \\
\hline Feature & Local adaptation of allocation rules of common pool resource \\
\hline Feature & Beneficiary involvement in the decision-making process \\
\hline Feature & Effective monitoring \\
\hline Feature & $\begin{array}{l}\text { Existence of sanctions that can be gradually applied to participants who violate } \\
\text { Community rules }\end{array}$ \\
\hline Feature & Easy and cost-effective access to dispute resolution \\
\hline Feature & Recognition by the high authorities of community self-management \\
\hline Feature & Multi-layered nesting firms in the form of organization \\
\hline
\end{tabular}

Source: Ostrom, 2015: 90.

Approximately 100 local fishermen were in Alanya coastal fishery work on boats of 2 or 3 people using various sizes of nets. Half of the fishermen belonged to the local production cooperative. The 1970s were considered to be the middle ages of Alanya fisheries. The economic life of fisheries in the 1970s is threatened by two factors (Berkes, 1986: 74):

- The over-exploitation of fishery causes hostilities which sometimes turns into violent conflicts,

- Competition between fishermen for better fishing points increases production costs and makes the level of fishes likely to catch uncertain.

In the early 1970s, members of the local cooperative began to try to allocate fishable locations to local fishermen. After 10 years of trial-and-error efforts, the rules used by the coastal fishermen of Alanya are as follows (Berkes, 1986: 73):

- Every September, a list of licensed fishermen in Alanya is prepared regardless of whether they are members of the cooperative or not.

- The fishing areas used by the fishermen in Alanya are generally named and recorded. They are spaced apart so as not to block adjacent fishing nets.

- Allocation of fishing locations is implemented from September to May.

- In September, suitable fishermen determine the location of fishing gear to be allocated to them by lot. 
- From September to January, every fisherman moves to the position in the east of them every day, after January fishermen move to the location in the west. This creates equal opportunities for catching shoals that migrate from west to east or vice versa.

- The mayor and the gendarmerie are also present during the lot. Surveillance and control of the system is provided by fishermen.

- If the central government officials tried to make this system, it would take a long time and cost for non-fishery appointed officers to succeed without gaining experience in the field.

\section{Conclusion}

Under the assumption that individuals are rational and have full information, common goods are confronting with the third best result which is far from the Pareto optimal equilibrium. Common pool resource can be nationalized to prevent this situation. Appointed officials of the central government may not know the features of the common good or at least it will take long time and high cost for them to learn. Another solution to avoid inefficiency allocation of common goods is granting the ownership to a person or an institution. However every country has not only its own statuory law and unenacted law but also common law and traditions. Privatizing the fishes in the sea is not available in the Roman law, Islamic law, Turkish civil code, customs and traditions. The third way except nationalization and privatization is governed by an organization consist of the people who are benefiting the common pool resource. Fishers from Alanya is an example of the third way of which consequence is not a tragedy of commons. If the individuals who are benefiting from the common good, can communicate each other in an effective way, can trust each other, can realise that they share both the common past and the future the consequence would not be a tragedy of commons.

\section{References}

\section{Journals/Periodicals;}

Berkes, F. (1986). "Marine inshore Fishery Management in Turkey." in Preceedings of the Conference on Common Property Resource Managment, National Resarch Council, pp. 63-83, National Academy Press.

Çetin, T. (2012 -1). "Yeni kurumsal iktisat”, Sosyoloji Konferansları, No:45, pp 43-73.

Ergüder B. \& Uymaz B. (2014). “Ortak Mallarin Geleceği: Ortak Mallar Çerçevesinde Mali Alanin Analizi”, Mali AlanTeori Uygulama, Berksoy, T.; Kesik, A.; Şahin, M., Ed., Seçkin Yayıncılık, Ankara, ss.107-139.

Hardin, G. (1968). "The tragedy of the commons", Science, vol. 162, pp. 1243-1248.

Kenneth, S. (1989). "Stidying institutions: some lessons from the rational choice approach" Journal of theoretical politics, Vol.1 no.2, pp. 131 -147.

Stilwell, F. (2019). "From economics to political economy: contradictions, challenge and change", American Journel of Economics and Sociology, Vol. 78, No:1, pp 35-62. 


\section{Books;}

Campbell, D.T. (1985). Background for the uninitiated. In Paradoxes of Rationality and Cooperation, University of British Columbia Press.

Dawes, R. M. (1975). "Formal Models of Dilemmas in Social Decision-Making." in Human Judgment and Decision Processes, edited by M. Kaplan and S. Schwartz. New York: Academic Press.

Olson, M. (1965). The Logic of Collective Action: Public Goods and the Theory of Groups, Harvard University Press.

Ostrom, E. (2015). Governing the Commons, The Evolution of Institutions for Collective Action, Canto Classics edition, Cambridge University Press.

Wall, D. (2014). The Sustainable Economics of Elinor Ostrom: Commons, contestation and craft, Routledge Press. 